\title{
State Management: Forms and Functions
}

\author{
by Jan-Erik Lane
}

The concept of strategic management has become more relevant today as the public sector is less uniform and more fragmented. In order to deliver public services, the government develops a strategy setting the agenda for various policy domains, outlining the objectives as well as the management mechanisms to be employed. The government has a bundle of resources at its disposal: civil servants, capital assets, fiscal resources, laws and regulations. Instead of sticking to old ways of organising public programs in a path dependent fashion, it may wish to reflect systematically over the options of reforming the organisation. The principal-agent approach offers a convenient model for analysing the pros and cons of the alternatives of public sector organisation.

Das Konzept des strategischen Managements hat angesichts der Diversifizierung und Fragmentierung des öffentlichen Sektors an Bedeutung gewonnen. Zur Bereitstellung öffentlicher Dienstleistungen entwickelt die Regierung eine Strategie, in der die Agenda für unterschiedliche Politikfelder festgelegt und die Ziele wie einzusetzenden Mechanismen konkretisiert werden. Den politisch Handelnden steht dabei eine Reihe von Ressourcen zur Verfügung: Humankapital, Infrastrukturen, fiskalische Ressourcen, Gesetze und Verordnungen. Statt an überholten Verfahren im Sinne der Pfadabhängigkeit festzuhalten, ergeben sich vielfältige Optionen für eine Organisationsreform. Der principal-agentAnsatz bietet ein geeignetes Modell zur Analyse der jeweiligen Vor- und Nachteile.

\section{Introduction}

Today after some decades of public sector reform, there is talk about holistic government. ${ }^{1}$ One often summarises the many changes in state management that have occurred during the recent twenty years with the thesis of a seminal movement from government to governance. But then one faces the challenging task of unpacking this wooly concept of "governance", whether it is a matter of multilevel, externalised, holistic or joined-up government. One may look upon the various forms and function of state management in a systematic manner, $a b$ stracting from the historical context of each major public sector reform. There

1 Leat, D./Seltzer, K./Stoker, G.: Towards Holistic Government: The New Form Agenda, Basingstoke, 2002; Bogdanor, V. (ed.): Joined-Up Government, Oxford, 2004; Pollitt, C.: Time, Policy, Management: Governing with the Past, Oxford, 2008. 
are long linkages over time, as Pollitt emphasises, time in itself does not determine the policy organisation chosen for a public service. This shift towards a new pattern of governance in well-ordered societies results from the employment of a number of public sector strategies, although not all are put in practice in the same way in all countries.

This new landscape - the macro picture - is the outcome of numerous choices about governmental forms to be employed in relation to public services - the micro view. More and more, governments in well-ordered societies enter these choices into a strategy for public sector change and renewal, based upon deliberations about organisational alternatives for the delivery of public services. Which are the main strategy options? And what are the main pros and cons from the point of view of the government?

\section{Interests and Institutions}

A new incoming government in a well-ordered country does not lack some degrees of freedom in framing its policies for organising delivery. Although it inherits the past with its constraints for the future, the government may initiate public sector reforms with a view upon strategic options to be pursued consistently over the years of the election cycle. Also when a government pursues a highly conservative state management policy, refraining from any major changes, it will be evaluated politically with definitive consequences for the prospects for the next election period.

A government in a well-ordered society is in possession of a huge set of resources - employees, capital, land, and fiscal means - that need to be organised for the purposes of service delivery to the population. Today the set of alternatives in organising these resources has been increased, following an intense period of public sector reform since the 1980s. In a post-Weberian period, governments will want to reflect over their management options in organising its supply of goods and services, comparing the relative advantages of bureaucracy with other alternatives. ${ }^{2}$ Assessing management forms - successes and failures - and comparing them with various measuring rods, governments engage in strategic state management, partly or comprehensively.

2 Kettl, D.F.: The Global Public Management Revolution, Washington, DC, 2000; id.: The Transformation of Governance, Baltimore, 2002; Reichard, C.: Introduction: Trend Towards a More Diversified Institutional Landscape, in: Public Management Review, 10/5 (2008), 569-571. 
Generally speaking, the management problem is to contract with a team of people at various locations to deliver services that create value while incurring reasonable costs. Given imperfections in information as well as a general tendency towards opportunism among people, governments cannot hope for a maximisation of value and a minimisation of costs. However, since a government has an interest in promoting social value and containing costs, because this enhances its electoral prospects, it will consider alternative management forms with of view of policy effectiveness.

It should be emphasised that strategic management of public sector change is based upon deliberations concerning benefits and costs in various governance forms. To the former belong the social benefits from more effective provision of services in combination with distribution effects for certain groups in the electorate. Into the latter enter on the one hand the costs of having various teams doing the job of providing public services - agency $\operatorname{costs}^{3}-$, and on the other hand the transaction costs from changing from one governance form to another - switching costs. A general framework for analysing the key issues in state management is offered in the principal-agent approach, where the government as the principal contracts with a variety of alternative agents - teams - to get the job done. ${ }^{4}$

The principal-agent approach belongs to rational choice institutionalism, insisting upon a clear-cut methodological separation between institutions and interests. ${ }^{5}$ When providing for public services, the government engages more or less in strategic thinking about how to organise its resources with the view of getting the job done. It may employ alternative governance forms - the bureau, the public joint-stock firm, internal markets, regulatory boards, special tribunals, ordinary courts, sub-national levels of governments, regional or global bodies (e.g. emissions trading) - where teams of people take action on a daily basis producing services. How they behave is determined by their preferences, or interests. Although it is true that the operations of alternative institutions, or governance forms, are not neutral in relation to the furthering of the interests of the actors involved, interests (preferences) and institutions (rules) must be kept separate analytically. Rational choice institutionalism may be combined with bounded

3 Alchian, A.A./Demsetz, H.: Production, Information Costs and Economic Organization, in American Economic Review, 62/5 (1972): 777-795.

4 Laffont, J-J. (ed.): The Principal Agent Model: The Economic Theory of Incentives, Cheltenham, 2003.

5 Friedman, J. E.: Rational Choice Controversy: Economic Models of Politics Reconsidered, New Haven, CT, 1996. 
rationality ${ }^{6}$ but it differs from sociological institutionalism that attributes agency to historical legacies or institutional patterns in themselves ${ }^{7}$.

Basically, one assumes in the principal-agent approach that government wants inter alia to maximise the social value of the services provided by the contracted teams, because success or failure in the provision of public services has strong implications for its electoral fate. The various agents want first and foremost to be paid for their work, including compensation for effort. The principal-agent framework, recognising the occurrence of uncertainty and opportunism with asymmetric information in steering mechanisms or governance schemes, ${ }^{8}$ covers not only the bureaux or regulatory boards but also the networks in multi-level governance as well as private entrepreneurs from civil society and incorporated firms, whether public or private. In a comparative institutional framework, one may analyse which management forms promote the best the interests of the politicians and which allows the delivery agents to capture a rent, meaning higher than necessary agency costs.

\section{Constraints from Trajectories}

The theory of state management is neither the copying of private management approaches onto the public sector nor the interpretations of country narratives. Instead it focuses upon the strategic options that governments face when deciding how to allocate its resources, personnel, real assets and financial wealth onto alternative governance forms in order to provide its population with public services. Each management form offers a choice option for how to organise the teams - public or private - who are to be held accountable public services. The set of organisational options is neither a copy of the alternatives in managing a private firm or an incorporated enterprise, nor is it a mere reflection of the country's past, its administrative history or institutional legacy. ${ }^{9}$ When theorising "Staatsgeschäfte" and their organisational requirements, then neither private sector profit maximisation models nor historical institutional images play the decisive role.

6 Williamson, O. E.: The Mechanisms of Governance, New York, 1999.

7 Katznelson, I./Weingast, B.R. (eds.): Preferences and Situations: Points of Intersection Between Historical and Rational Choice Institutionalism, New York, 2007.

8 Williamson, O.E., op. cit.

9 Kickert, W. (ed.): The Study of Public Management in Europe and the US, London, 2008. 
Below I concentrate upon the reforms of public services and regulation modes, discussing the pros and cons of some of the major organisational alternatives in recent policy making. I will not go into the debate on public redistribution and the alternative framings of pension and income compensation systems. I will argue that the principal may wish to embark upon strategies in public sector reform, i. e. consistent policy-making over a set of options about how to structure the supply of public services. Of course, some governments have no strategy at all but jump from one option to another.

The interests of the government would be related to the outcomes of public services, meaning citizen satisfaction, voter approval and economic growth in wellordered societies. By enhancing value in society in a broad sense, governments increase their popularity and the probability of re-election. This is especially important for politicians acting under party government. If the set of politicians in power during one election period fails in the delivery of services, then they hurt the prospects of their political party in the upcoming election period. Thus, party government disciplines politicians to abstain from myopic policies and self-interests and take a longer time perspective, focusing upon efficiency in public services.

Productivity in service delivery is one factor that contributes to effectiveness in outcomes, but it is not the only one as distributional matters also count. In order to promote social value, governments face a number of strategic choices of how to line up its teams and resources. There is no single best model, as all alternatives of public sector organisation have their pros and cons. Assuming that a government will take both production or agency costs and transaction costs into account, one may list some of the major governance forms and their pros and cons.

\section{The Policy Organisation and Public Management}

Governments are constantly engaged in the making and remaking of policies, whether at the national level, the sub-national level or at the regional and international level. One may look upon each policy domain as people interacting in setting up and running a policy organisation, as outlined early by Meltsner and Bellavita: 
"Public managers are expected to do more with less, and their public organizations are supposed to be better managed. There is, however, more agreement on the objective of improving management than on how to do it."10

This statement is as relevant today as it was in the 1980s when written down ahead of the New Public Management movement. Their concept of a policy organisation for a policy area or domain fits well with neo-institutionalist emphasis upon governance forms:

"[...] the problem of how to improve governmental performance is to understand that the choice of public management lies between finding ways of increasing self-control or responsibility of members and using organizational structure and process to accomplish objectives."11

Yet today, this changing policy organisation in each policy domain has taken the shape of the boundary less structure or process employing most recently available means of communication in order to draw upon several management forms. ${ }^{12}$ It is the diversity or heterogeneity of the policy organisation today that makes strategic management crucial, as public management involves alternative forms in the same policy domain: bureaucracy, internal markets, networks, nonprofit organisation, public-private partnerships, outsourcing and multi-level linkages. Given the break-up of the monolithic bureaus, whether in the soft sector (departments, agencies, administrations, boards) or in the business sector (trading departments), governments, whether national, regional or local, are in need of a new cement to hold the multiplicity of agents together - strategic management is the response. What, then, are the basic options in strategic public management, meaning the governance forms to choose in the policy organisation?

\section{Incentives}

When analysing governance forms and their probable consequences for outcomes, ${ }^{13}$ whether in the public or the private sector, it is essential to recognise the possibility of failures, as Williamson ${ }^{14}$ has underlined. When new institutions are put in place in a policy organisation, then there may occur unintended out-

10 Meltsner, A./Bellavita, C.: The Policy Organization, London, 1983, 13.

11 Ibid., 13.

12 Ashkenas, R.N./Ulrich, D./Jick, T.: The Boundaryless Organization: Breaking the Chains of Organizational Structure, San Francisco, 2002.

13 Ostrom, E.: Understanding Institutional Diversity, Princeton, 2005.

14 Williamson, O. E.: Markets and Hierarchies, New York, 1983. 
comes that may even be unrecognised for some ${ }^{15}$ due to institutional bending, meaning that the incentives of the employees and stakeholders involved take over. In the provision of public services, whether produced publicly or privately, the providers have strong incentives to get paid, although the remuneration may take alternative forms such as long-term or short-term contracting. The agents responsible directly for the provision are in it for the sake of money, at least to a considerable degree. Strong incentives push agents towards opportunism with guile in Williamson's terminology, meaning that opportunism may occur in alternative management forms. It cannot be eradicated by however complex institutional mechanisms one designs. The strength of the principal-agent framework within rational choice institutionalism compared with sociological or historical institutionalism is the emphasis on the implications of incentives when theorising state management.

\section{Options in Strategy}

All other things equal, the principal wants to employ an agent or set of them like a team who maximise social value through service provision while demanding a reasonable remuneration in terms of salary and perquisites, to be paid from the value of the output. The agents on the other want to maximise their wages and fringe benefits, not hesitating to engage in opportunism with guile. This conflict of interest in the common effort to provide services to the population sets up principal-agent games, which the principal may attempt to master by means of strategic management. The principal will search for management forms and functions that minimise rent-seeking from the agents, like for instance monitoring, tendering/bidding, network involvement, judicialisation and hiving off to another principal (downwards or upwards) or engaging the private sector. The principal wants high effort agents, where "high effort" in principal-agent theory stands for all that makes an agent competent, loyal and motivated. But high effort always costs more than low effort. And it may be merely a promise.

Thus, the government as the principal would, ceteris paribus, seek the management forms that most favour its interests, allowing for the role that various tactical considerations may play. When structuring its provision of services in terms of a set of institutions, it has to take into account the interests of the agent and how the various institutions promote these. Institutional change is likely when 
the principal finds institutions that better serve his/her interests and are less likely to be captured by the interests of the agents. Besides taking the interests of the agents into account, the principal also views how information asymmetries can be balanced, for instance by inviting agents with transaction specific information to work for him/her. Let me discuss some of the main forms and functions in strategic state management, albeit shortly.

\section{The Agencification Option: From Bureaux to Executive Agencies}

Public teams of people working for government, i. e. the executive, used to be organised according to one model, the government department. This has the bureau type of institutions, combining hierarchy with a high degree of division of labour. Since it is almost entirely funded over the budget, approved by the legislature, the government department has tended to be a statutory body, enshrined in administrative law. This type of institution scores high on rule of law considerations, but it hardly accomplishes efficiency in outputs or outcomes. This has led governments to seek alternative ways of structuring public teams of employees. Bureaucracy is an institution that is conducive to moral hazard due to the longterm nature of the contracts involved, which used to be called "slack" before the principal-agent model called it "shirking". The government may employ the strategy of monitoring the bureaux continuously, but it is transaction cost heavy.

As the difficulty with the bureau is its inclination to generate slack in various forms, the government may wish to strike at the foundation of its power, namely the long-term nature of the relationship between the principal and the agents in bureaucracy. With tenure, there is bound to arise moral hazard, as bureaux develop into a world of their own, becoming immortal, as it were. To counteract bureau strategies, government needs to engage in monitoring but it is transaction costly and also not strategy proof due to collusion between the bureau and the monitors.

One strategy is to make the teams more controllable for the government by eliminating their tenure and separating them from statutory protection. This is the executive agency model, taken to its extreme in the reorganisation of Whitehall but also employed in reinventing government in Washington, DC. Agencification in general involves strategic management aiming at reducing production costs by means of short-term contracting and the separation between policy and implementation. With a little bit of fantasy, the principal may set up a variety of agents for specific purposes to be reviewed and perhaps renewed after some 
years of existence. The core of agencification is the imaginative use of NDPBs non-departmental public bodies. It is not confined to the UK with its special "quangos" or "fringe bodies". ${ }^{16}$

Agencification as a strategy of management has the disadvantage that it easily runs into too much complexity. When departments are broken up into separate agencies with teams contracted on a short-term basis, there is bound to arise transaction costs. When these become staggering, then there is the risk of a garbage-can process, where the principal loses control over his/her many agencies.

\section{The Networking Option: Relying upon the Stakeholders}

Setting up a network offers an attractive option compared with agencification, which may lead to an organisational zoo with somewhat strange animals from the point of view of rule of law. Networks are also flexible creatures that can be set up without legislative approval. They would operate on a limited time basis, drawing upon the altruistic motivation of its participants. But this option of structuring teams is only available where voluntary participation is forthcoming and the principal has trust in the ensuing teams.

Governments make conduct a deliberate strategy of engaging with civil society, trusting voluntary organisations or community groups with the provision of services, especially social services or cultural ones. The non-profit organisations (NPOs) or non-governmental organisations (NGOs) may be entrusted with tasks either with sole responsibility or by participation with agencies, public or private ones. They are in some ways easier for government to handle, as their participation is based upon altruistic motives, at least to some extent. The networking strategy of eliciting support from the community in joined-up government is often considered as response to the complexity of the post-modern society, with the government making its contribution to building up social capital.

Networks may emerge either as a result to explicit design - the Dutch examples. Or they may result implicitly from growing complexity - the UK and US examples. ${ }^{17}$ Networking as a strategy for the government is attractive when the stakeholders possess asset specificity or transaction unique information. It is also highly relevant when altruistic motives enter the effort of the agents. The cons of

16 Wettenhall, R.: Agencies and Non-Departmental Public Bodies: The Hard and Soft Issues of Agencification Theory, in: Public Management Review, 7/4 (2005), 615-635.

17 Goldsmith, S./Kettl, D.F.: Unpacking the Power of Networks, Washington, DC, 2009. 
networking as a strategy stem from the constant difficulty of defining the borders of the network and of stabilising its authority and financing.

\section{The Incorporation Option: From Trading Departments to Joint-Stock Companies}

Only in relation to the business sector is the joint-stock model a true option in strategic state management. The private company institution - Aktiengesellschaft - makes sense where there is a constant cash flow, money coming and money going out. In the business part of the public sector, the trading department fulfilled this requirement. The huge public enterprises were organised as trading departments. For the politicians their usefulness was double. On the one hand, they secured a stable but inefficient supply of much needed public services. On the other hand, the many jobs within these giants could be given to party supporters.

The neo-liberal revolution in public policy undermined this coalition of interest underneath the public enterprise institution. It called for the elimination of the slack in the public enterprises through deregulation and open entry. To governments facing deficits this new message promised the doing away of subsidies over the budget to these firms, if an institutional option could be found that sanctioned the lay-off of people. Incorporation was the answer, as the rules of the joint-stock companies do not allow for the running of enterprises in deficits under normal circumstances. And they allow the owners to refuse to cover losses due to the limited liability rule. Numerous examples of incorporation can be found in telecommunications, electricity and gas as well as railroads and transportation: Deutsche Bahn, Deutsche Post, Electricité de France (EDF), Gaz de France (now GDF Suez) as well as Endesa and Enel. The incorporation of some of the giants in the public enterprise sector has created huge global players that behave like multi-national firms. This raises the question of the basic objective of incorporated and partially privatised public firms: Who is the ultimate principal: the nation-state or the population? When these giants make huge profits, then it leads to spectacular increases in the remuneration of the CEOs. But when transnational strategies go wrong, then the risk assumption by the principal entails a moral hazard dilemma in principal-agent theory.

Take the example of energy provision in Sweden. In the old system, there were two large public enterprises, Vattenfall and Sydkraft, owned respectively by the state and Southern local governments. With incorporation, deregulation and 
privatisation, Vattenfall expanded outside of Sweden into mainly Germany while German giant E.ON took over Sydkraft. No major improvement in outcomes has been noticeable by this change in governance form, as some would even claim that a few palpable organisational failures have at times been noticeable.

In incorporation, there were hardly any large transaction costs involved when changing from one institution to another. When the quantity of provision started to decline as the size of the workforce could be trimmed there was hardly much public protest. But when charges or the user fees began to increase, citizens raised their eyebrows, wondering whether higher profits in these public utilities were in the so-called public interest. The incorporation option received strong backing from the managers of the public enterprises, moving quickly to demand increases in pay in order to close the gap to private firm CEOs. Thus, the incorporation strategy can very often be backed by strong incentives from the influential players and little resistance from the public at large. Transaction costs tend to be negligible. ${ }^{18}$

\section{The Privatisation Option: Semi-Public or Fully Private?}

Sometimes one strategy fits with another. Incorporation may be a step towards divestiture. It is actually a rational means to that end, because government will be properly informed about the value of the stock it owns in the Aktiengesellschaft. When government uses the incorporation option, it is then interested in knowing the value of its shares. One way to get that information in a reliable manner is to list the company on the bourse and sell some of the stock over the stock exchange. Putting up a part of the shares for sale is conducive to a market based assessment of the new firm as well as of its income earning capacity in the future. But it also gives government the option of complete privatisation.

Privatisation is a strategic option from two angles. On the one hand, it offers a revenue source that may be handy in times of deficits. On the other hand, it may be employed as a management device when less than 50 per cent of the shares are offered to the market or special investors. Government is very interested in information about how its joint-stock companies are run. This sets up a principalagent game with lots of asymmetric information. Instead of constantly monitoring the CEOs, which is transaction cost heavy, the government relies upon the market assessment in the evaluation of the performance of its company. Full 
scale privatisation was embarked upon strategically in mainly the UK, partly for ideological reasons. ${ }^{19}$ However, privatisation of SOEs may be conducted as a strategic tool to raise as much revenue as possible and level the playing field in the entire economy. ${ }^{20}$

\section{The Regulation Option: From Deregulation to Reregulation}

The government has the power to make legislation concerning economic activity, i. e. engage in public regulation. The options concern how much and how? The philosophy of regulation is a central piece of strategic state management, outlining what governments ought to regulate in the market economy as well as how they can go about doing so with some probability of success.

Traditional public regulation targets the problem of natural monopolies, suggesting that government regulate these enterprises, whether they are public (European style) or private (American style). Deregulation as strategy involved that the government on the contrary introduces policies that open up entry, removing barriers to market access. The basic goal is not to set up a system of price and quantity regulations by means of licenses but to guarantee a level playing field. A decision for any of these two options for regulation policy - the Cambridge philosophy against the Chicago School - was taken in the global deregulation movement that started in the late 1970s, favouring the Chicago theory according to Stigler's interpretation. One outcome of this kind of state management was the creation of the Single Market all over Euroland with adjacent countries. Was then the issue of regulation removed from state management?

On the contrary, the scope and range of public regulation is one of the most debated topics in state management today. The trend is clearly towards reregulation. And much effort has gone into theorising how a government is to accomplish that. Pursuing the idea of levelling the playing field, governments want to treat public and private producers on an equal footing, especially when it comes to the provision of public services. The challenge for state management is to offer citizens venues for quality control and assessment. Reregulation is the strategy where government creates boards for overview, evaluation or complaint, with an overview of the quality of the provision of public services.

19 Vickers, J./Yarrow, G.: Privatization: An Economic Analysis, Cambridge, MA, 1988.

20 Megginson, W.L./Netter, J.M.: From State To Market: A Survey of Empirical Studies On Privatization, in: Journal of Economic Literature, 39/2 (2001), 321-389. 
Given the variety of public services, reregulation may lead to a truly scattered pattern of boards. Reregulation may become so widely employed that government overinvests in this strategy with the attending carbage can outcomes. ${ }^{21}$ Reregulation may be politically an opportune strategy, shuffling criticism for poor management under the carpet of a complaints board, presumably neutral and effective. Yet, reregulation tends to leads to a plethora of boards that government cannot control. Actually, principal-agent theory was first applied to the public sector in models of agency autonomy, ${ }^{22}$ arguing that regulatory boards have an inbuilt drive to modify the original goals laid down by its principal, the Congress - the theme of goal displacement in classical public administration. ${ }^{23}$

\section{The Marketisation Option: Contracting Out or Contracting In?}

In traditional state management the government relies upon bureaucracy to get the job done. New Public Management delivered a new strategy, namely the internal market model. The idea was to undo the asymmetric information advantage of the bureau by market testing its service provision, both costs and quality as well as quantity. When done on a large scale, this strategy changes the nature of government completely, transforming bureaucracies both at the central level of government and at the local governments. Yet, the model in itself is merely an extension of public procurement, which is what governments have done a long time, especially in the US.

Setting up an internal market emphasising government as buying and selling calls for a strategy of contracting, either contracting out with external suppliers or contracting in with its own employees, now organised as independent result units or even as joint-stock companies. The marketisation strategy can be partial or comprehensive, voluntary or imposed by the parliament, combined with executive agencies or incorporation, etc. It can result in networks replacing bureaucracy and consisting of both public and private providers in complex contracts.

Often the term "externalisation" is employed for a comprehensive strategy of marketisation in combination with incorporation or privatisation with contracting

21 Pollitt, C.: New Labour's Re-disorganization: Hyper-Modernism and the Costs of Reform - a Cautionary Tale, in: Public Management Review, 9/4 (2007), 529-543.

22 McCubbins, M.D./Noll, R. G./Weingast, B.R.: Structure and Process, Politics and Policy: Administrative Arrangements and the Political Control of Agencies, in: Virginia Law Review, 75/2 (1989), 431-482.

23 Merton, K., op. cit. 
out. The advantages for the government as principal lies mainly in reducing costs, while the disadvantages stem from rising transaction costs in handling all the short-term agreements that may have to be enforced by a third party. Local governments all of Europe, from Scandinavia to Italy, have been interested in "externalisation" in order to reduce their burden for providing an increasing set of public services. ${ }^{24}$

The marketisation strategies all attempt to market test the agents providing public services. Since the comparative cost advantage will only surface when there are multiple bidders, the emphasis in these strategies is upon erecting schemes for tendering and bidding that are strategy proof, meaning that no form of corruption is involved when all these contracts are awarded, neither on the part of the principal nor on the side of the agents. Marketisation runs the risk of adverse selection on the part of the principal, failing ex ante to recognise the nature of the agent and incurring switching costs ex post when contract terms are not fulfilled.

\section{The Multi-Level Governance Option: Hiving Off to another Principal}

A classical strategy in almost all public sector reforms has been the effort of the central government to hive off activities, making the central government less burdensome and more manageable. Besides NPM strategies there is the often used a decentralisation or deconcentration strategy, the former moving functions to lower tiers of government and the latter placing activities with local or regional branches of the central government, basically moving them from the capital. The decentralisation or deconcentration strategy was a key element in the classical approach of public administration and has been neglected in principalagent theory applied to the public sector. ${ }^{25}$

Decentralisation has been the most persistent strategy in public sector reform in well-ordered societies. The central government as principal transfers tasks and competences to the principal of a lower level jurisdiction. The advantage to the central government is that it may shed some duties in order to concentrate upon other ones, deemed more politically important. In particular, the central government wants to offload the responsibility for day-to-day service provision onto

24 Thynne, I. and Wettenhall, R. (eds.): Symposium on Ownership in the Public Sphere. Special issue of International Journal of Public Policy, 5/1 (2010).

25 Moe, T.M.: The Politics of Structural Choice: Toward a Theory of Public Bureaucracy, in: Williamson, O.E. (ed.): Organization Theory: From Chester Barnard to the Present and Beyond, New York, 1990, $116-153$. 
other principals. Deconcentration involves that the central government hires other people than agencies in the capital bureaucracy to deliver the services. It could an agency at the regional level - the prefect type - or it could be a local agency, or a set of them. Whereas decentralisation is an affaire between two or more principals, deconcentration implies a change of the agent solely. Both stem from the burden of central government overload, leading the principal to neglect important strategic matters being divulged in program details.

The government may not only reflect upon the option of transferring tasks and competences down to the regional level in its political system. It now also has the option of going intergovernmental or supranational. In a region of countries where there is considerable economic integration, government may pursue the strategy of political coordination, delegating numerous tasks and competences to intergovernmental or supranational bodies, like for instance the EU Council or the EU Commission.

Regional integration is an interesting strategy for government as it allows it to draw upon economies of scale in policy-making and policy implementation. By sharing the responsibility for regulating the economy with other governments like for instance information gathering, it reduces the overall costs of regulation as well as secures harmonisation with other governments within the region. The more interdependent the country with its regional neighbours, the more costly is autonomy with the danger of isolation.

Regional integration is also a risky strategy for a government, as a new set of agents emerges who opt naturally for increased autonomy in relation to their principals. Thus, the EU Commission is a giant set of agents for the Council of European nation-states, but it serves first and foremost the Union. The option of multi-level governance is especially attractive for governments facing externalities, like on environmental issues in Europe. ${ }^{26}$

\section{The Judicialisation Option: How Much Reliance upon Special Agents like Judges?}

In a well-ordered society whatever strategy the government engages in concerning how to structure its agencies, personnel and capital resources, it has to respect the exigencies coming from the notion of rule of law in a broad sense. But

26 Knill, C./Liefferink, D.: Environmental Politics in the European Union. Policy-Making, Implementation and Patterns of Multi-Level Governance, Manchester, 2007. 
how much to judicialise the public sector is a choice option. When the government entrusts the ordinary courts, administrative courts or special tribunals with power over policy-making and implementation, then it faces an agent who is different from the agents normally employed for getting the job done. Courts constitute the judicial branch of government, and although paid by the government they operate with a special autonomy, backed by not only constitutional or legal provisions but also by a strong professional ethics that is sui generis. Shortly expressed, the courts do not take any directives from the government in a well-ordered society. In theory, they engage in interpreting and adjudicating law, not politics. In practice, judges or courts may have political clout, especially when the government accepts to increase the scope for legal review or constitutional testing of laws.

The government may use judicialisation as a strategic option in order to handle sensitive political issues, like the rights and duties of minorities, the enforcement of human rights and the respect for due process of law. Judicialisation is like decentralisation a strategy of reducing government overload. Judicialisation may follow an ad hoc strategy introducing several tribunals, which may be contrasted with the strategy to employ a set of standard administrative courts for the handling of grievances in the public sector.

Yet, sometimes the creation by government of more avenues for grievances, complaint and redress is less motivated by a willingness to help citizens to correct its bureaucracies but a disguised measure to protect these. Special tribunals may have high requirements for accepting complaints by citizens, use time consuming practices with long delays. In the end the tribunal may look for ways to interpret the rules so that the criticism of the service provider is weakened, although emphasising its culture of objectivity and neutrality.

Judicialisation opens the door to a new actor on the political scene, the judges. They have their own principal, namely the idea of rule of law and right reason. The motivation of judges is typically activist, meaning that once they get the foot into the domain of politics they strive to enlarge their influence by means of a series of case rulings. Thus, one understands that some governments may be hesitant about too much judicialisation, especially if they adhere to the doctrine of parliamentary supremacy. 


\section{The Green Option: Ex Ante and Encompassing?}

The spectacular increase in political saliency for environmentalism calls for a strategic response from government, given that markets do not voluntarily protect ecology values - a gigantic market failure according to the 2006 Stern Report. The question of what strategy to take in relation to domestic and international ecology matters is at the heart of present day policy debates between cornucopians and ecologists. On the one hand there is the choice between law, taxes and emission or abatement rights. On the other hand, there are the two policy alternatives of ex ante measures and ex post measures. When making environmental policy, the government may rely upon state authority using laws or the market, trading with emission or abatement rights.

In an ideal-type strategy of environmental policy-making, the government would call for environmental impact assessment ex ante in a comprehensive manner as well as apply the polluter pays principle ex post on each and every market failure. This would amount to a full-scale policy strategy towards environmentalism and a green economy. Outstanding issues for an ecology strategy include the mix of policy instruments: law, taxes and rights. Contested is also the status of the precautionary principle, which when applied ex ante may appear to be too restrictive for future risk taking.

The French government has embarked upon a most ambitious strategy for an ecology policy, involving obligatory environment impact assessment both ex ante and ex post, the introduction of a taxe carbone and the construction of new nuclear sites to reduce the dependency upon fossil fuels. It amounts to a huge commitment that will take many years to implement in a coherent manner, if feasible at all. A country like Brazil on the contrary has little of ecology policy, accepting or even tacitly endorsing the destruction of its most unique asset, the Amazonas. Some small countries like for instance Sweden have embarked on a most ambitious ecology strategy involving considerable costs, but one must recall that almost $80 \%$ of all greenhouse gases are emitted by the G20 countries, some of which have no ecology strategy at all.

The government of South Korea has declared its intention to install comprehensive green policy organisation as well, moving the country towards a future green economy, involving not only more of energy efficiency in consumption but also the generation of new forms of energy that does not result in greenhouse gases. Given that Seoul has considerable air pollution, this is a major change in the direction of state management with implications of South Korea's global 
industries. It remains to be seen whether environmentalism will become the major policy consideration in strategic management, not only in terms of a new and better global policy organisation but also nationally.

\section{Future Management Forms}

One can, of course, only speculate about future developments when it comes to the structuring of the policy organisation. The dominance of the nation-state will be reduced while regional and international policy organisations will grow in importance, one may predict. The main reason is the need for the nation-states in the world to coordinate upon a policy organisation - an international regime for handling climate change. However, also local communities are bound to play a more important role in policy-making, either separately or in joined-up forms of collaborative governance.

\section{Copenhagen Policy-Making: The Paradox in a Global Emissions Regime}

As governments around the world change their preferences, away from the "cornucopians" à la $A$. Wildavsky towards the "deep ecologists" à la $A$. Naess, they would share a willingness to enter intergovernmental regimes for handling spillovers, regionally or globally, especially controlling the greenhouse gases that may wreck complete havoc in this century. When policy matters are global, then supporting an international regime offers the most effective strategy to managing the problems. However, setting up a policy organisation on a global scale against climate change and engaging in strategic management in reducing the carbon equivalent emissions is beset not only by the classical collective action difficulties (free-riding, reneging, cheating), but it stumbles upon a true paradox - the Copenhagen dilemma, outlined in Figure 1.

Figure 1 portrays the basic problem that the Copenhagen meeting faces: per capita emissions against total country emissions. It would seem just that countries with high per capita emissions take most of the burden of a future cap on the emission of greenhouse gases. However, the crux of the matter is that only the United States has both high per capita emissions and huge total emissions. Only by cutting total emissions a global regime can be effective. But total emissions are highest in the populous and industrialising Asian countries. Thus, a significant reduction in carbon emissions must involve active participation in a global policy organisation - an international regime - by the large industrialising 
Figure 1: Carbon equivalent emissions: per capita and total

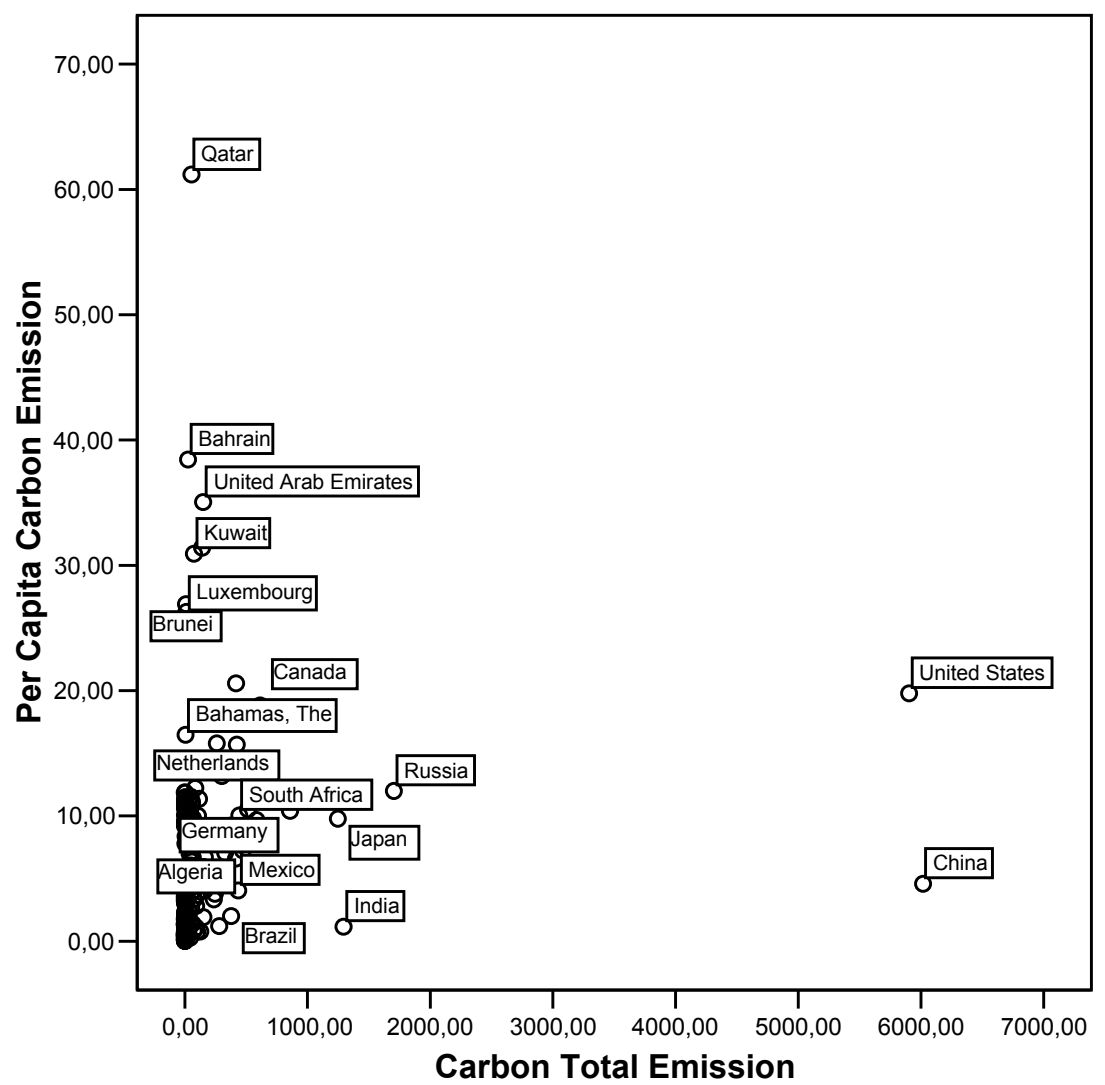

Source: http://www.eia.doe.gov/environment.html.

countries in South Asia, East Asia and South East Asia as well as advanced Japan and South Korea. It will not be effective for merely countries with high per capita emissions to make huge reductions. Carbon emissions are linked with population size. Thus, the call for countries with high per capita emissions to help paying for the cost of reducing the huge emissions in emerging economies arises, combining a global ecology policy with redistribution from rich to poor countries.

Whether a global regime employs a carbon tax or an emission rights trading scheme, the problem of policy enforcement is mind-boggling. If this global policy organisation employs a carbon tax, then who is going to pay at the end of the 
day - poor or rich countries? And what is the tax money to be used for? Similarly, the carbon trading organisation faces great uncertainties: How will the emission rights be created - how much grandfathering? And what to do with countries that burn down the rain forest while receiving support for reducing carbon emissions from energy consumption?

Going regional or international as a strategy for setting up a policy organisation is an attractive option when there are strong externalities or spillovers between countries. A regional or international regime poses the problem for a nation-state of how it can monitor that its rules meet with effective enforcement.

\section{Generation of Social Capital}

Instead of looking upwards towards regional or international organisation as a strategy for managing problems that do not stop at the national borders, the nation-state may look downwards towards the lowest tier in the political system, the local community. The local government has become highly relevant for the new ambition of governments to build social capital and enhance community values through for instance collaboration with the NPOs or NGOs - the civil society. ${ }^{27}$ Thus, one encounters today numerous policies that reach out to third sector organisations, inviting them to participate in public-private partnerships, offering culture - exhibitions, conferences, festivals etc. - in a broad sense to the community. Building trust by creating networks with non-profit organisations or non-government organisation constitutes a strategic response to the search for value integration in the post-modern society with its cultural diversity - a policy organisation for the multicultural society. ${ }^{28}$

"Social capital" like the "public sphere" have become buzz words in policymaking circles, as trust is increasingly regarded as a key element in building and maintaining urban and rural communities. Since our interactions with friends, family, workmates or community groups add to that useful resource, social capital, the local government may develop a strategy of how to enhance everyday activities that contribute to our store of social capital, promoting activities that are most beneficial, and demoting those which threaten or deplete this resource. ${ }^{29}$

27 Thynne, I./Wettenhall, R., op. cit.

28 Leonard, R./Onyz, J.: Social Capital and Community Building: Spinning Straw into Gold, London, 2004.

29 Field, J.: Social Capital, London, 2008; Lane, J.-E./Wallis, J.: Non-Profit Organizations in Public Policy Implementation, in: Journal of Public Administration and Policy Research, 1/7 (2009), 141-149. 
Strengthening the public sphere is a closely linked policy theme that comprises strategies for expanding public ownership, although of immaterial aspects of community life like communalities in values, environmentalism and ethnic integration. Instead of distinguishing clearly between the public and the private, as in classical political economy, policy-making inspired by the philosophies of Habermas, Bourdieu and Coleman aims to bridge borders and fill empty spaces with social interaction and community cultures. It is sometime a matter of quite substantial public contributions from the budget to civil society, building public ownership as a virtual policy organisation for trust building.

\section{Basic Choice Alternatives: Long-term Contracting, Short-term Contracting, and Trust}

When setting up a governance structure in relation to the allocation of a public service, the government has three options: long-term contracting with monitoring, short-term contracting with tendering and bidding and finally trust in partnerships with civil society or networks. These three management forms have different implications for the realisation of the intentions of the government. When agents possess unique expertise, which takes a long time to acquire, and transaction costs are heavy, then the government would be interested in opting for long-term contracts, although the risk of moral hazard increases. As transaction costs go down, the government may consider short-term contracts, which reduce the dangers of moral hazard. Governance through tendering and bidding tends to reduce agency costs but may increase switching costs when there is adverse selection. The more the government develops competence in running schemes of tendering and bidding, the more attractive become outsourcing and marketisation. Finally, the government may wish to draw upon the motivational assets within third sector organisations, entrusting delicate tasks with NGOs through the build-up of networks.

\section{Fundamental Structures: Authority, Markets and Networks}

The set of public services in a well ordered society - law and order, education, health care, communications, energy, water provision and waste disposal etc. play a major role in the life of citizens. How they are provided matters much in terms of both allocative efficiency and distributional equity. Governments used to meet the demand for public services by means of their authority, as expressed in budget appropriations, legislative regulations and state monopolies. Public 
sector reform has meant that governments have engaged in other governance forms. Through incorporation and public procurement as well as internal the scope of market activities has increased considerably, calling for a new regulatory strategy, focusing upon a level playing field with the private sector. Finally, governments have had an ambition to explore governance forms outside of traditional bureaucracy and the market institutions, setting up and supporting networks of a variety of participants and stakeholders, drawing upon motivational altruism to some extent. Bureaucracy has in no way been undone, as it provides governments with stability at the cost of inertia. The range of marketisation of public services is basically determined by the scope of business activities in the public sector. The resort to networking is an attractive strategy for governments when the public services in question involve asset specific knowledge and a dose of personal commitment.

\section{Conclusion: Strategic Management and Policy Organisations}

When new politicians, whether right or left arrive, in the positions of government in well-ordered societies, they face a number of strategic options concerning how to structure the machinery of government and the public sector in order to get the job done, meaning providing public services in a broad sense. It is true that established organisations handling the delivery of services in the public sector tend to survive for quite some time - call it positively incrementalism or negatively inertia. But recent public sector reforms have made a reflection over the pros and cons of the alternatives in public sector organisation more relevant than during the period of public sector growth after the Second World War. ${ }^{30}$ Inherited institutional practices may be overturned by large scale public sectors, strategic considerations weighing more than institutional trajectory or path dependency.

In the well-ordered societies, i.e. countries that institutionalise the rule of law together with the market economy, a hectic public sector reform period of two decades has increased the alternatives of action for the government, making new options for structuring the public sector available that did not exist or were not considered earlier. ${ }^{31}$ Governments may now deliberate upon these options with a view upon long-term objectives, elaborating strategic management.

30 Bouckaert, G./Pollitt, C.: Public Management Reform: A Comparative Analysis, Oxford, 2004.

31 Osborne, S. P.: The New Public Governance, London, 2009. 
The arrival of e-government offers a handy tool for governments to both increase their contacts with their basic principal, the electorate, and to steer their various agents - internal or external, under public law or private law, long-term or short term - in a manner that reduces the asymmetric information typical of management in all forms and functions. ${ }^{32}$ E-government restricts the applicability of the traditional approach to public administration or management, disjointed incrementalism, favouring strategic management.

The aim of this article has been to weigh the pros and cons of some of the main management options in the public sector reform debate, although it must be admitted that also short-term tactics play a role for politicians, such as electoral appeal and popularity with stakeholders like the business community, civil society or trade unions.

32 Lips, A.M. B./Schuppan, T. (eds.): E-Government and Institutional Change. Public Management Review (Special Issue), 11/6 (2009). 